\title{
ビルマ米袋積海上輸送における倉内実験
}

\section{Some Experiments on Carring Burma \\ Rice in Ship's Holds.}

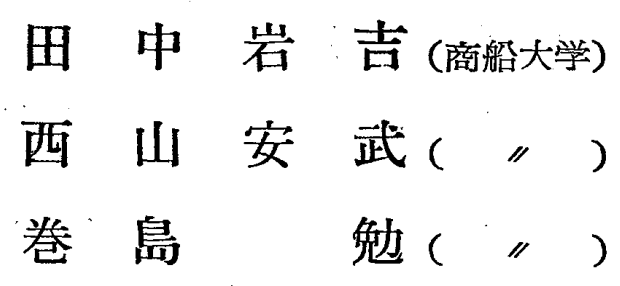

\begin{abstract}
It is customarily required by surveyors to set wooden ventilators among rice bags carried by sea. Besides the researches made by the present authors there has been made no measurement or discussion of the quantitative efficiency of wooden ventilators and stowing methods of rice in bags in the ship's hold. Many of the changes in the quality of the rice may be the effects of the solar radiation, the temperature of sea water, atmosphere and ship's shell plates and the air condition in cargo spaces.

The authors tried to find a better method of stowing bags of Burma rice and their proper management during the voyage. They measured the humidity, temperature, air velocity and moisture ratio of rice, setting many measuring points in and out of ship's hold.

They noticed the following facts.

1. The temperature of the upper deck plates rose as high as $60^{\circ} \mathrm{C}$ in the daytime and the heat flux into the hold reached $190 \mathrm{Kcal} / \mathrm{m}^{2} . \mathrm{h}$. and there was almost no changes of the temperature inside the cargo throughout the voyage from Burma to Japan, though the temperature fell considerably as the ship neared Japan.

2. There was some air flow inside the wooden ventilators at all times through the voyage. And its average velocity was $0.1 \mathrm{~m} / \mathrm{sec} \sim 0.7 \mathrm{~m} / \mathrm{sec}$. The velocity of the air flow was as great as $2 \mathrm{~m} / \mathrm{sec}$ inside the trench in the cargo. The continuous air flow inside the wooden ventilators, however, had little or no effect on the cargo temperature.

3. There was no gain of moisture ratio of the rice, either. But some condensation of moisture was seen on the skin of the ship, inevitably caused by the cooling down of the ship's shell plates near Japan.

We can say that there was no changes of temperature and moisture ratio of
\end{abstract}


rice in the ship's hold throughout this transportation from Burma to Japan.

\section{I まえがき}

ビルマ米等外米の袋積海上輸送は、従来慣行の木製ベンチレーターを貨物内部に插入する積載 法が採用されて来たが、ての積載法に対する検討即ら外気、水温、日射その他が倉内空気及び袋 米温度、含水率等に及济す影響、叉木製ベンチレーターの効果等につき定量的検討が未だなされ てんなんので、今回実船て上る諸計測をなし、袋米積付及び輸送管理の方法に検討を加えた。

\section{II 実験概要}

1. 実 験 期 日 : 昭和31年 1 月 26 日 昭和31年 3 月 4 日。

2. 航路：玉〜モールメイン〜大阪。

3. 実 験 場 所 : 赤倉山丸第 2 番倉。

4. 積載貨物及び数量 ： ビルマ米、22/56 S. A. M.B. N/JAP. 15. M16/015 1601bs.

$$
107,500 \text { bags, } 7957^{010} \mathrm{G} / \mathrm{L} / \mathrm{T} \text {.満船 }
$$

5. 実 験 方 法 : 第 2 番倉 (袋米満載) 飞附図 I 飞示す各種測点を設置、下記

により諸計測をなした。

倉内空気温湿度、外板、袋米内部温度、外板の熱流量、日射状海 (30分隔測)

倉内風速、対船風速、天気、外気温湿度、太陽観測、船首方向 ( 2 時間隔測)

海水温度 ( 4 時間隔測)

その他外米の含水率等を航海中適宜測是

\section{III 実験結果}

附図 1.2. 3. 4. 5. 6. 7. 及び表 1.2 参照

紙面の都合で計測結果全部を発表出来ないため、その代表的な一部分のみにとどめをが結果か ら見ると、外気、海水温度が安定し、死㤝規則正しん日变化を繰返するのと見られる前半、即ら 2 月28日（此島北端西方海上）迄と、その後時間とともに质病一定の割合で温度降下をするもの と見られる後半とに分けられる。

前半…水温は $28^{\circ} \mathrm{C}$ を中心し振幅約 $1^{\circ} \mathrm{C} 、$ 気温は $27^{\circ} \mathrm{C}$ を中心とし振幅約 $2^{\circ} \mathrm{C}$ 程度の大体周 期変化飞近い変化を繰返す極く安定せるものである(附図 5 )。上甲板、舫側外板（水線上）温

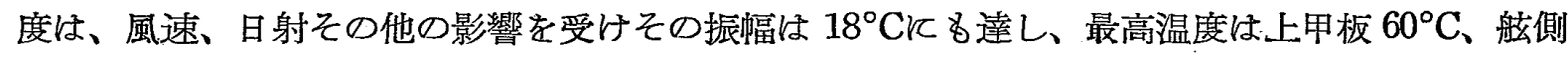
外板 $48^{\circ} \mathrm{C}$ k達した（附図 2)。外板温度の最低は夜明けに水温気温 と大体同一或は多少低め迄降 下する。上甲板に殸ける倉内外への熱流は、外板温度が日射量に激しく爷配されるので多少の不 規則はあるが、周期変化に近ん変化をなし、日中良内への最大流入量は $190 \mathrm{Kcal} / \mathrm{m}^{2}$. h. 亿達 した。夜間は日没直後の倉外への流出量がやや大きいが、日之出迄大体一定の Heat flux 15〜 $25 \mathrm{Kcal} / \mathrm{m}^{2} \cdot \mathrm{h}$ で流出している（附図 4)。全航海にわたり各一日当り毎時の熱流量を附図 4 亿示 す。

後半…気温、水温こるに降下を始め、多少の不規則はあるが時間につき一定の割合一 $0.14^{\circ} / \tau$ で降下している(附図 5)。これとともに熱流子倉外へ流出を続けている(附図4)。

水線下の外板温度は往航時の計測により常時水温と大体一致してんそのて、復航には計測を中 止、海水温度のみを測定した。文船風速とともに木製ベンチレーター内部その他倉内各所の微風 速を測定し、ベンチレーター内部に常時空気の流動を認めた。トレンチ内は他部に比し風速大で 
$2 \mathrm{~m} / \mathrm{sec}$ 亿も達したが、木製ベンチレーター内部最大 $1 \mathrm{~m} / \mathrm{sec}$ で大体 $0.1 \mathrm{~m} / \mathrm{sec} \sim 0.7 \mathrm{~m} / \mathrm{sec}$ 程度であり、水平ベンチレーターより垂直役設置せるものの方が大きい傾向を認めた。又米の含 水率任積揚時とともに、航海中適宜水分測定ををし、航海中は中甲板貨物上面のものだけ測定し $\hbar_{\circ}$ (表1)

\section{IIII 実験解析}

1. 記号

$t_{\mathrm{s}}$ : 甲板温度 $\left[{ }^{\circ} \mathrm{C}\right]$

$t_{c} \quad:$ 貨物温度 $["]$

$t_{r} \quad$ : 倉内空気温度 ["]

$t_{1}$ : ベンチレーター入口空気温度 ["]

$t_{2}$ : ベンチレーター出口空気温度 [》]

$\mathrm{t}_{e}$ ：ベンチレーター内部平均空気温度 ["]

$\mathrm{C}$ ：有効輻射常数 [K cal $\left./ \mathrm{m}^{2} . \mathrm{h} .{ }^{\circ} \mathrm{K}^{4}\right]$

$\mathrm{C}_{d}$ : 上甲板裏面輻射常数 ["]

$\mathrm{C}_{c}$ ：貨物表面輻射常数 [”]

$\mathrm{C}_{b}$ : 黒体輻射常数 [ /] ]

$\mathrm{R}_{x}$ : 貨物内深さ $x^{m}$ 激ける温度振幅 $\left[{ }^{\circ} \mathrm{C}\right]$

$\mathrm{R}_{x=0}$ ：貨物表面に揞ける温度振幅 [”]

$\boldsymbol{\kappa}$ : 貨物の温度伝播率 $\left[\mathrm{m}^{2} / \mathrm{h}\right]$

$\lambda \quad$ ：貨物の熱伝導率 $\left[\mathrm{Kcal} / \mathrm{m} . \mathrm{h} .{ }^{\circ} \mathrm{C}.\right]$

c : 貨物の比熱 $\left[\mathrm{Kcal} / \mathrm{kg} .{ }^{\circ} \mathrm{C}\right]$

$\rho$ : 貨物此重 $\left[\mathrm{Kg} / \mathrm{m}^{3}\right]$

$\tau_{0}:$ 周期 [h]

$\tau \quad$ ：時間 [h]

W : ベンチレーター内部を流れる空気の水当量 $[\mathrm{kg} / \mathrm{h}]$

$\mathrm{S}$ ：ベンチレーター内壁の伝熱面積 [ $\left.\mathrm{m}^{2}\right]$

v ：ベンチレーター内部の空気流速 [ì/sec]

$\mathrm{d}$ ： ベンチレーターの流体力学的直径 [m]

$\alpha \quad$ ：貨物表面熱伀達率 [ $\mathrm{Kcal} / \mathrm{m}^{2} . \mathrm{h} .{ }^{\circ} \mathrm{C}$. $]$

$\mathrm{F}_{0}$ ：上甲板に系ける熱流量 $\left[\mathrm{Kcal} / \mathrm{m}^{2}\right.$. h.]

\section{2. 上甲板温度変化の貨物温度への影響}

貨物上面温度は、輻射その他の熱伝達が定常状態にある場合は(1)式により求められる。

$$
\begin{aligned}
& 2 \mathrm{C}\left(\frac{t_{s}+273}{100}\right)^{4}-2 \mathrm{C}\left(\frac{t_{c}+273}{100}\right)^{4}-\alpha\left(t_{c}-t_{r}\right)=0 \ldots \ldots \ldots . . . \\
& \text { ここで } \quad \mathrm{C}=\frac{1}{\frac{1}{\mathrm{C}_{a}}+\frac{1}{\mathrm{C}_{c}}-\frac{1}{\mathrm{C}_{b}}} \text { (有効輻射常数) }
\end{aligned}
$$

々屯 $\mathrm{C}_{a}=4.06^{(1)}, \mathrm{C}_{c}=4.00^{(2)}, \mathrm{C}_{b}=4.96, \alpha=5.3^{(3)}$ 
とし実測せる $t_{r}, t_{s}$ 、により航海中の貨物上面温度の最高最低を求めれば表 2 となる。 又厚さ無限大と見做す壁表面温度が振幅 $R_{x=0}$ なる周期変化宗する場合、深さ $x^{m}$ の貨物内部 温度振幅 $R_{x}$ の減衰率 $A$ は(2)式となる。

$$
\begin{aligned}
A & =\frac{R_{x}}{R_{x=0}}=e^{-x \sqrt{\frac{\pi}{\kappa_{\tau_{0}}}}} \\
\therefore \kappa & =\frac{x^{2} \pi}{\left(l_{n} A\right)^{2} \tau_{0}} \ldots \ldots \ldots . .
\end{aligned}
$$

袋米を積載せる倉内を均一体亡見做し、貨物表面の温度変化の振幅を表 2 より求め、とれが周 期変化するものとし、貨物内部（深さ0.6m）の測点区1の実測值（附区 5) から (3) 式によりそ の温度伝播率 $\kappa$ を求めると、 $\kappa=0.005 \mathrm{~m}^{2} / \mathrm{h}$ とをる。乙れは袋間の気流、Broken space 等を

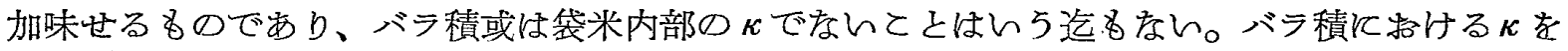
モデル実験により求めを結果、梁さ $0.2 \mathrm{~m}$ 以内で $0.0002 \sim 0.0007$ となた。これは熱伝導の 微分方程式の係数が場所の函数である為に変化するもので、これにつんての検討は後日に譲る。 即ち袋積状態の米の温度を論采る場合は、袋の周囲の気温と袋内部の温度と二段階飞別けて検討 する必要がある。

てれ等 $\kappa の$ 值より、表面温度が周期変化する場合、その周期温度変化の影響を受けない（表面 温度振幅 ${ }^{1} / 100$ ） と見られる梁度を(2)式により求めれば、 $\kappa=0.005$ で $x=0.9^{m} ， \kappa=0.0002 \sim$ 0.0007 で $x=0.1^{m} \sim 0.7^{m}$ となり温度の影響は極く表面のみとなる。

\section{3. 通風筒内の気流と温度变化}

木製ベンチレーター内部の気流飞ょり倉内貨物より奪う熱量 $Q(K \mathrm{cal} / \mathrm{h})$ は

$$
\begin{aligned}
& Q=\left(t_{1}-t_{c}\right) \mathrm{W}\left(1-e^{-\frac{\alpha S}{W}}\right) \ldots \ldots \ldots \ldots \ldots \ldots \ldots \ldots \ldots \ldots \ldots \ldots \ldots \ldots \ldots \ldots \ldots \ldots \\
&
\end{aligned}
$$

ベンチレーターの長さ即ら伀熱面積 $S$ が無限大の場合の $Q$ max は

$$
Q \max =\left(t_{1}-t_{c}\right) \mathrm{W}
$$

となる。

ベンチレーター内部の気流の水当量Wは、空気の湿度により多少異るが、主として流量をる風 速に支配されるが、ベンチレーター内部風速は $1 \mathrm{~m} / \mathrm{sec}$ 以下で Wは小で、航海の前半をる最も 換気を必要とする間は、 $\left(t_{1}-t_{c}\right)$ も小 (附図3) であるので、その食内熱量の排除は微量で冷却 效果は期待出来ない。

まを流入空気のベンチレーター内部通過による温度変化は(6)式により求められる。

$$
t_{2}=t_{c}+\left(t_{1}-t_{c}\right) e^{-\frac{\alpha S}{W}} \ldots \ldots \ldots \ldots \ldots(6)^{(7)}
$$

ベンチレーターの周囲である内部温度と初期流入気温の差は $e^{-\frac{\alpha S}{W}}$ るる減衰率で減少し、べ ンチレーターから入る空気の温度は次第に内部温度に接近する。計算によれば初期温度差の $90 \%$ まで上昇するに要する流入距離は、風速 $0.1 \mathrm{~m} / \mathrm{sec} \sim 2 \mathrm{~m} / \mathrm{sec}$ の範囲で6m〜 $12 \mathrm{~m}$ となり、2m〜 $4 \mathrm{~m}$ 程度の流入距離で、空気温度は既に初期温度差の $50 \%$ も上景するととになつて、木製ベンチ 
レーターの冷却効果壮余り期待出来なんてとになる。実測結果からもとのととが裹付けられる (附図3)。

\section{4. 水溫気溫が次第に下降する場合の倉内温度変化}

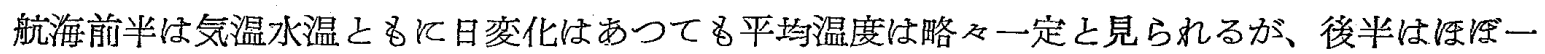
定の婧合で降下してんる。

ある均一体がはじめ内部まで一定の温度であるとき、表面温度が時間につを一定の劃合で変化 する場合の内部温度変化は(7)式で表わされる。

$$
t_{c}=k_{T}\left\{\left(1+\frac{x^{2}}{2 \kappa \tau}\right) \operatorname{erfc} \frac{x}{2 \sqrt{\kappa \tau}}-\frac{x}{\sqrt{ } \frac{x}{\pi \kappa}} e^{-\frac{x^{2}}{-4 \kappa \tau}}\right\} \cdots \cdots \cdots(7) \text { (8) }
$$

$\kappa=0.005$ とし(7)式とより梁さ $0.6 \mathrm{~m}, 1 \mathrm{~m}, 2 \mathrm{~m}$ の倉内温度を計算すれば附図 5 となる。本計 算值亡実測值 1 とは大体同一変化をなしているので、固体熱伝導の方程式が第一近似として適 用出来ると見て差支えない。

\section{5. 袋積状態の倉内熱伝導率並びに比熱の值。}

$\kappa=\frac{\lambda}{c \rho}$ であるから $c$ 及び $\rho$ を決定すれば $\lambda$ は求められる。袋積状態を均一体とした $c$ 及び $\rho$ を決定するには幾多の問題があるので、んま上面よりの熱通過量を用んて計算を進める。上甲 板熱流の実測によれぱ、日没より日出迄恃大体一定の熱量が食外へ流出している、表面よりの熱 流が一定で最初の表面温度が一定である場合、表面温度の降下は(8)式となる。

$$
t_{s}=\frac{2 F_{o}}{\lambda}\left(\frac{\kappa \tau}{\pi}\right)^{\mathrm{I} / 2} \ldots \ldots \ldots \ldots \ldots \ldots \ldots(8)^{(9)}
$$

即ち温度降下は時間の平方根飞比例する。又実測甲板裏温度降下は、日没後略及一-1.3 $\sqrt{\tau}$ で あり、ん委 $F_{o}$ の平均值を一 $15 \mathrm{Kcal} / \mathrm{m}^{2} . \mathrm{h}$. $\kappa=0.005$ を用いると $\lambda \div 0.9 \mathrm{Kcal} / \mathrm{m} . \mathrm{h} .{ }^{\circ} \mathrm{C}$ を得 る。

他方上甲板の熱流は、日中は倉内へ、夜間は倉外飞流れ、これが正弦波的変化をするすのとす れば、表面温度振幅 $R_{x=0}$ は(9)式となる。

$$
R_{x=0}=\frac{\kappa^{\mathrm{T} / 2}}{\lambda \omega^{\mathrm{T} / 2}} F_{0} \cdots \cdots \cdots \cdots(9)^{(10)}
$$

こてで $\omega=\frac{\pi}{12} / \mathrm{h}, F_{0}=70 \mathrm{Kcal} / \mathrm{m}^{2} . \mathrm{h} \quad \kappa=0.005 \mathrm{~m}^{2} / \mathrm{h} \quad R_{x=0}=9^{\circ} \mathrm{C}$ こすれば、 $\lambda \doteqdot 1.07 \mathrm{Kcal} /$ m.h. ${ }^{\circ} \mathrm{C}$ とる。実際の熱流変化は正弦波形をなして志ら和、几几 状を呈しているが、てれに より計算しても入の值て大しを影響を与えない。大体の傾向は合つているので以上の理論は第 一近似として使えるものと見られる。結局 $\lambda$ の值は、 $\lambda \div 1 K \mathrm{cal} / \mathrm{m} . \mathrm{h} .{ }^{\circ} \mathrm{C}$ と推定される。一方 第 2 番倉内積載量と容積から $\rho \div 670 \mathrm{~kg} / \mathrm{m}^{3}$ として比熱 Cを求めると、

$$
\mathrm{c}=\frac{\lambda}{\kappa \rho} \div 0.3 K \mathrm{cal} / \mathrm{Kg} \text {. 即ち比熱恃約 } 0.3 \text { 程度と見られる。 }
$$

\section{6. 米の含水率}

米の含水率は徽類発生、発熱等その変質に大をく影響するが、14.5\%以下では涹透压の関係で 徽類発生が困難とされている。含水率は空気の関係湿度に平衡して変動し、内藤氏実験 ${ }^{(1)}$ によ れば附図 6 の如ぐる。航海中倉内空気状態の測定結果は附図 7 の通りであつて、これによれ ば、3月1日以後は関係湿度が多少減少しているが、大体 $80 \%$ 内外であるから、予想される米の含 
水率は $15 \%$ 前後と見られる。然し実測含水率は表 1 であり。実測による航海中の含水率の変動は わ和沉認められるが、全般として積荷当時から航海を経て揚荷に至る迄の積載米の水分は殆ん ぼ変化していない。内藤氏の実験は極く微量（2g程度）の米粒を空気に充分に接触させを場合 で、而も平衡状態に達する迄に6日〜8日を要したのであるから、袋入りで積付けられを状態で、 これと倉内換気量等を考慮すれば、貨物全体から見て含水率の変化倞んど無いと見て差支えな $n_{0}$

\section{$\mathrm{V}$ 考 察}

以上各項にわをり解析を進めをが、本実験は初回であり、使用計器にも不備があつをので本実 験を以つて結論を求める段階ではをんが、赤倉山丸に和ける実験てつんては、下記の事項が考え られる。

1）航海前半をるビルマより南支那海迄の航海では日中甲板等の温度は $60^{\circ} \mathrm{C}$ 以上にも及び、倉 内への熱流が相当あつて、貨物上面温度は上昇したが、貨物全体への温度影響は徽弱であつた。

2）貨物間に插入する木製ベンチレーター内部の風速は $1 \mathrm{~m} / \mathrm{sec}$ 以内のものを常に認められる が、倉内温度を低下せしめる程の效果は余り期待出来をん。但しトレンチの效果は相当あるるの と見られる。

3) 台湾附近ょり内地迄の気温、水温の下降による倉内温度の変化は緩慢で、袋積貨物内部 $2 \mathrm{~m}$ の所になれば殆んど変化がない。温度下降し始めてから内地到着迄の短期間には、倉内袋米温度 の降下は僅少で積荷当時亡殆んご同一温度 $\left(\right.$ 約 $\left.30^{\circ} \mathrm{C}\right)$ ）で内地々到着してんるので、その間の輸 送上気温その他の変化のため米への悪影響は認められない。

4) 米の含水率も亦積荷当時と大体同一状態で輸送を完了して扣り、叉米の水分を高める現象も 殆えぞなん。後半多少の発汗はあつても、上甲板温度が大気の露点以下となつては、食内空気の 露点はそれ以上であるから、その発汗は不可抗力で、とれの防止には木甲板を張るとか、カーゴ ーろヤー装置の利用等特别の装置無くしては不可避のととである。デリックポストを利用せるへ ンチレーター内壁の発汗は、その露出部長大であるそめ、発汗激しくその汗が内壁を伝わり貨物 上飞落下、内部の米迄汗需れが多くなるので、かかるベンチレーターは汗除けを設けるとか、ダ ンパーで閉鎖しを方がよん。

5）全般から見て米の温度、水分は航海中を通して積荷より決して悪条件にはをつていないし、 殆んぞそのままの状態で輸送を完了していると見て差支えない。

6) 本実験に祘んて各測点に設置した湿度計が不正のため、倉内空気の湿度、発汗現象等につを 充分な究明が出来なかつをが、との問題は袋米輸送上の事故防止として最も重要ま点であるか ら、他日計器の完成を委つて実験するととにしたん。

\section{V あとがき}

以上の実験は日本船主拹会の昭和29年度上り 30 年度にわをり交付されを研究補助金を以つて行 われたものであつて、これが実施には井船舶株式会社の絶大なる御便宜をらけ、同社所属安土 山丸、有馬山丸、榛名山丸にて予備実験の後、ビルマ米の輸送に従事しを同社船赤倉山丸に便乗 して、乗組員諸氏の御協力のもとに本実験を行つをものである。との実験てつんては 同社のほ か、日綿実業株式会社、株式会社東京計器製造所、海外貨物検查株式会社、会糧庁、日本海事検 定協会等多数の方々の御支援を受け、御助言を賜つそことを厚く御礼申上げます。 


\section{附因 1 苐2番船含則点配置図}

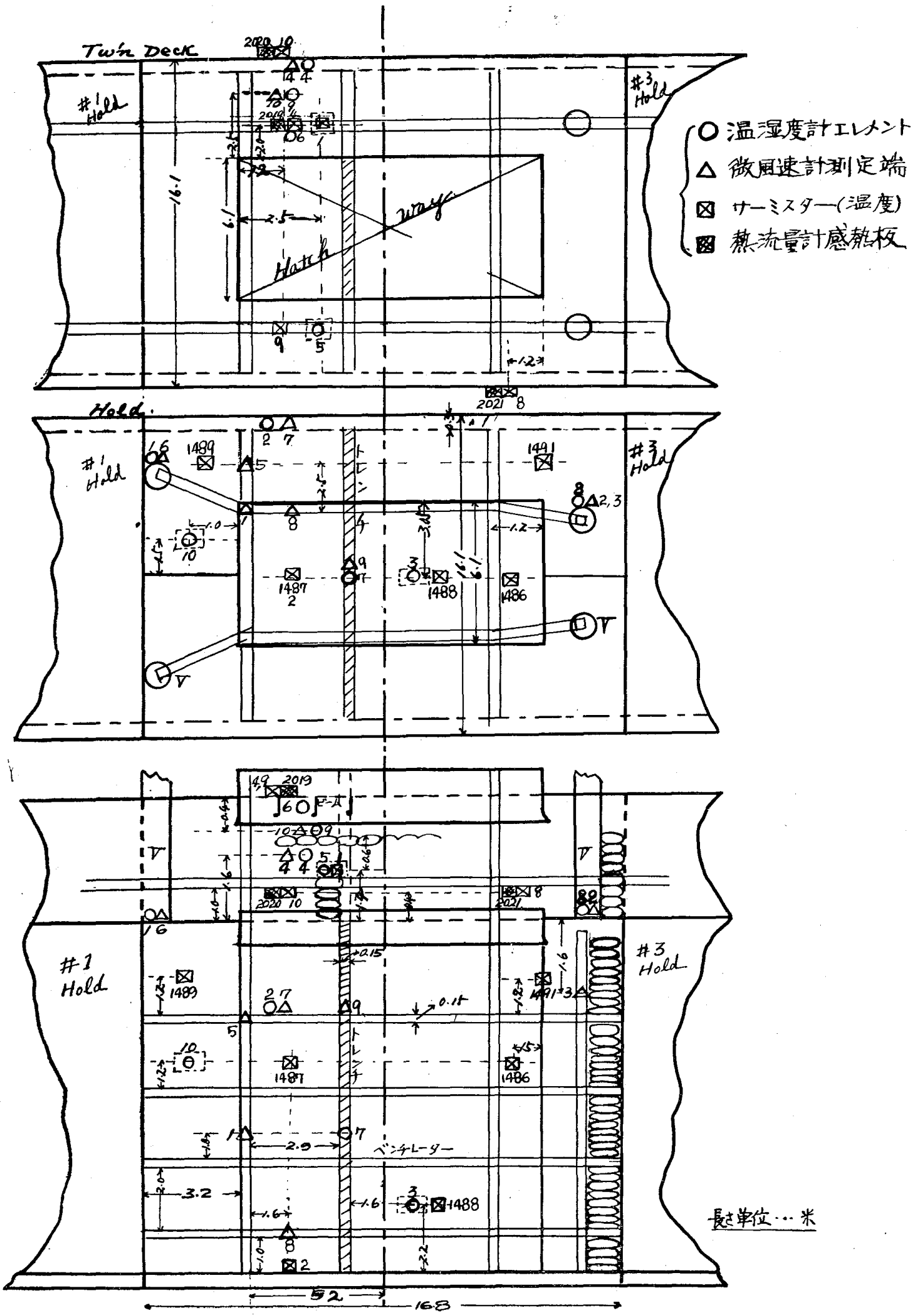




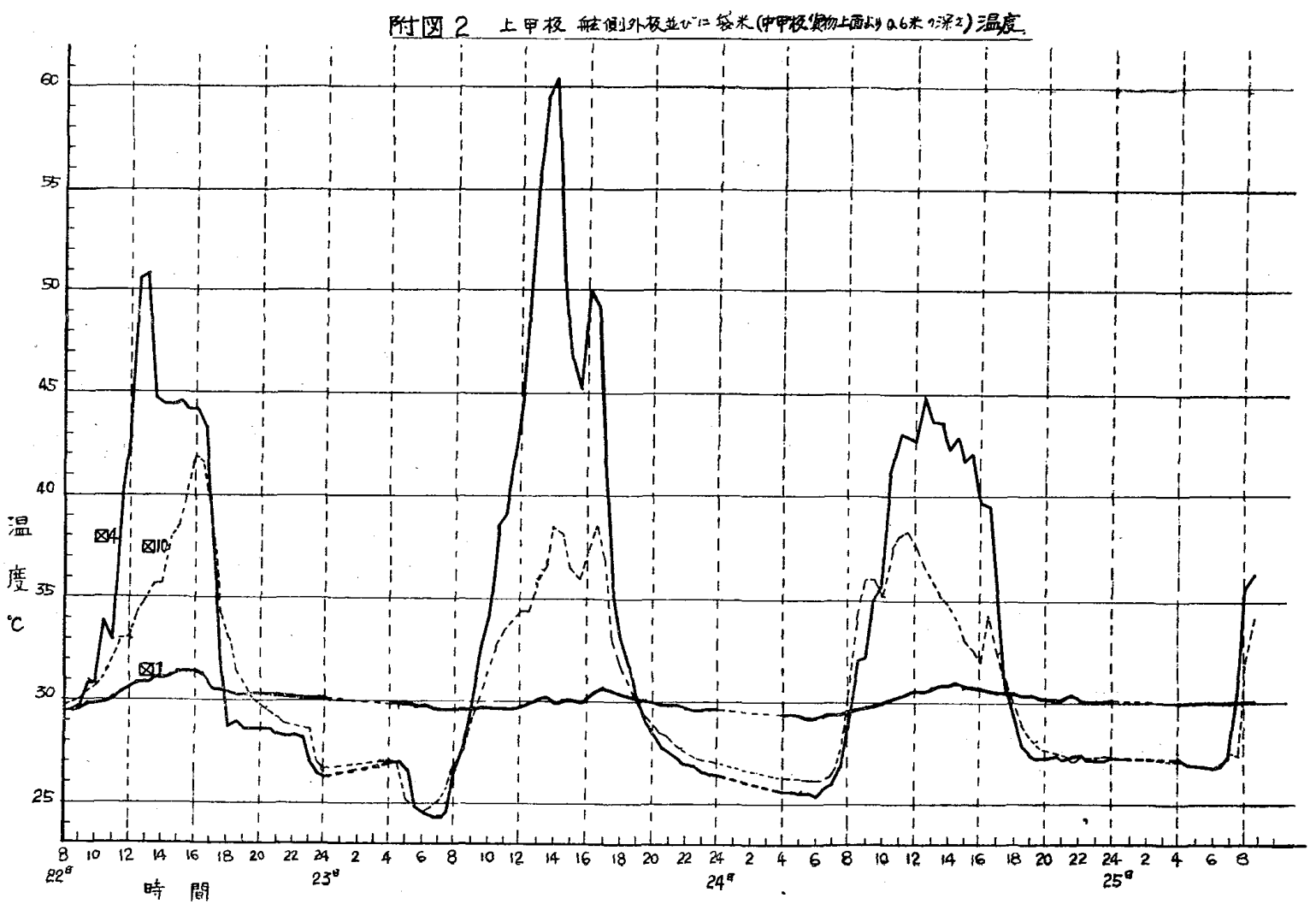

附图了含内上甲枚裹べンチレーター内部の氮温

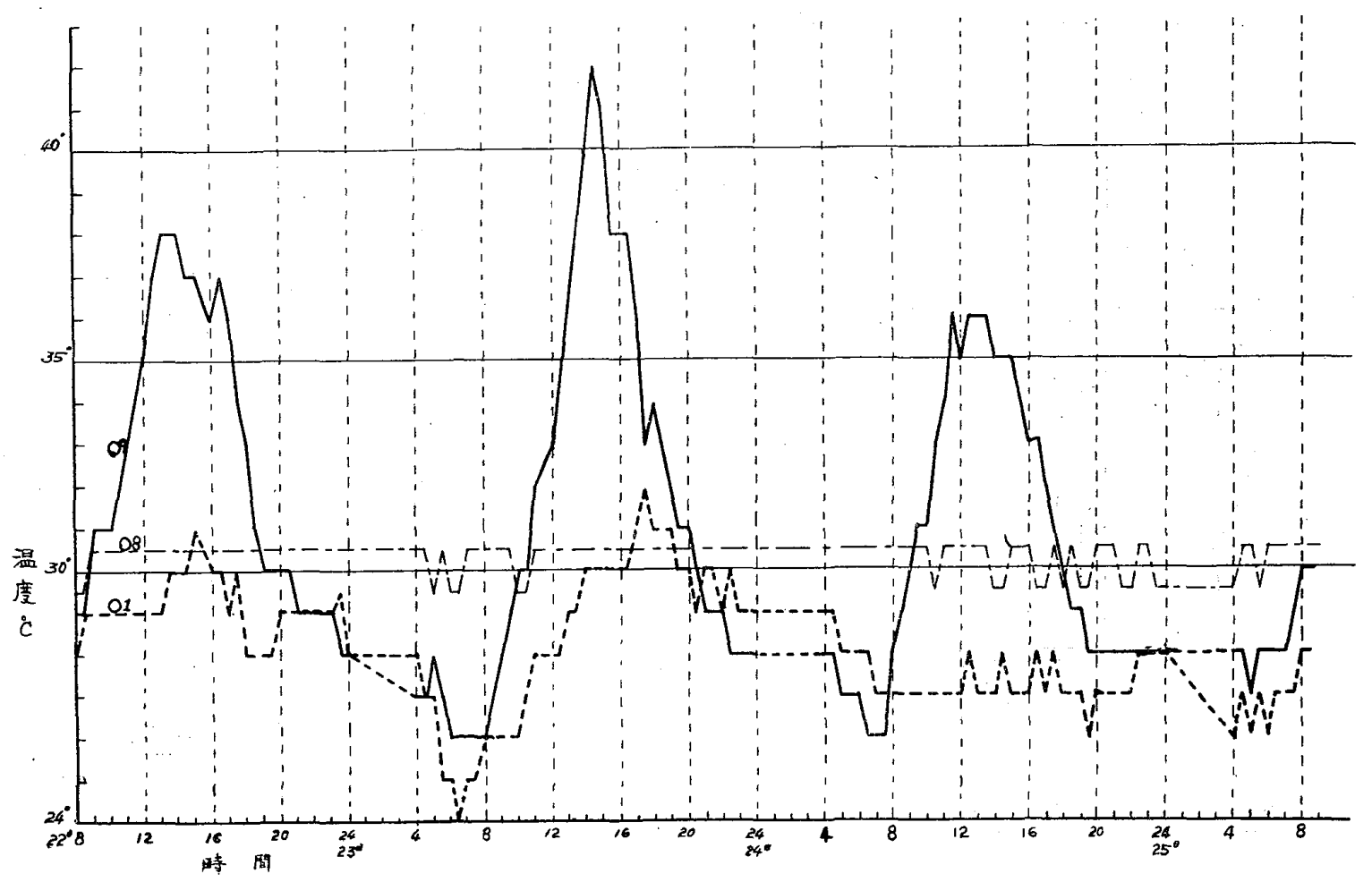


附図4

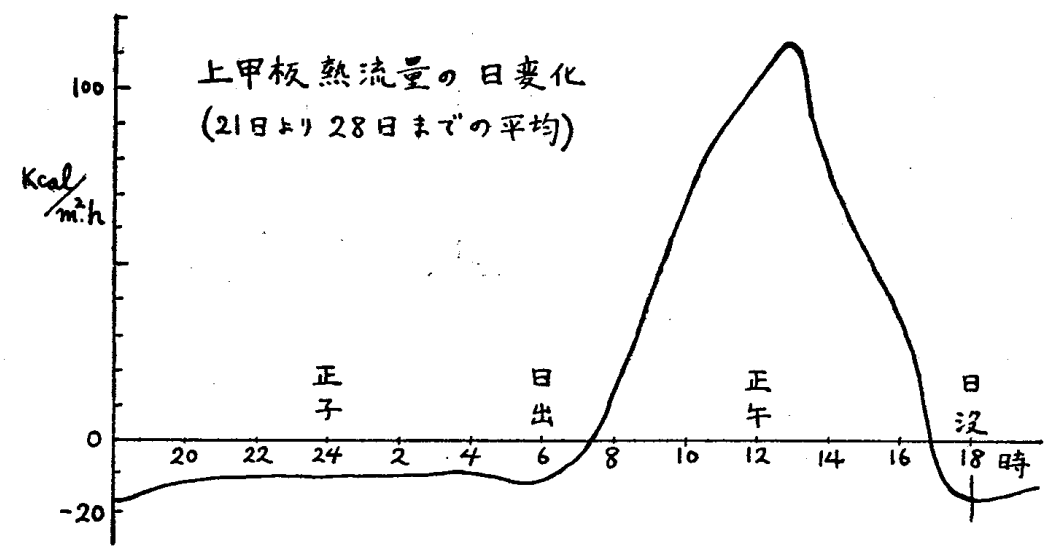

一日当りの每時熹流量

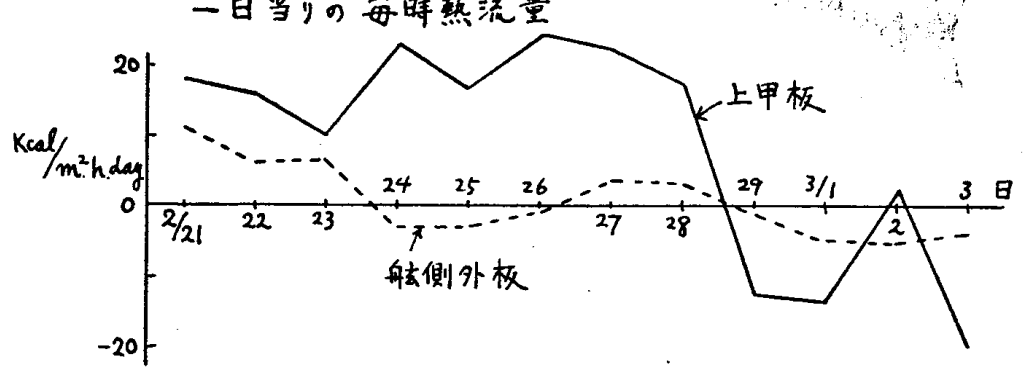

附四 5. 水温。动温及び含内袋米温度

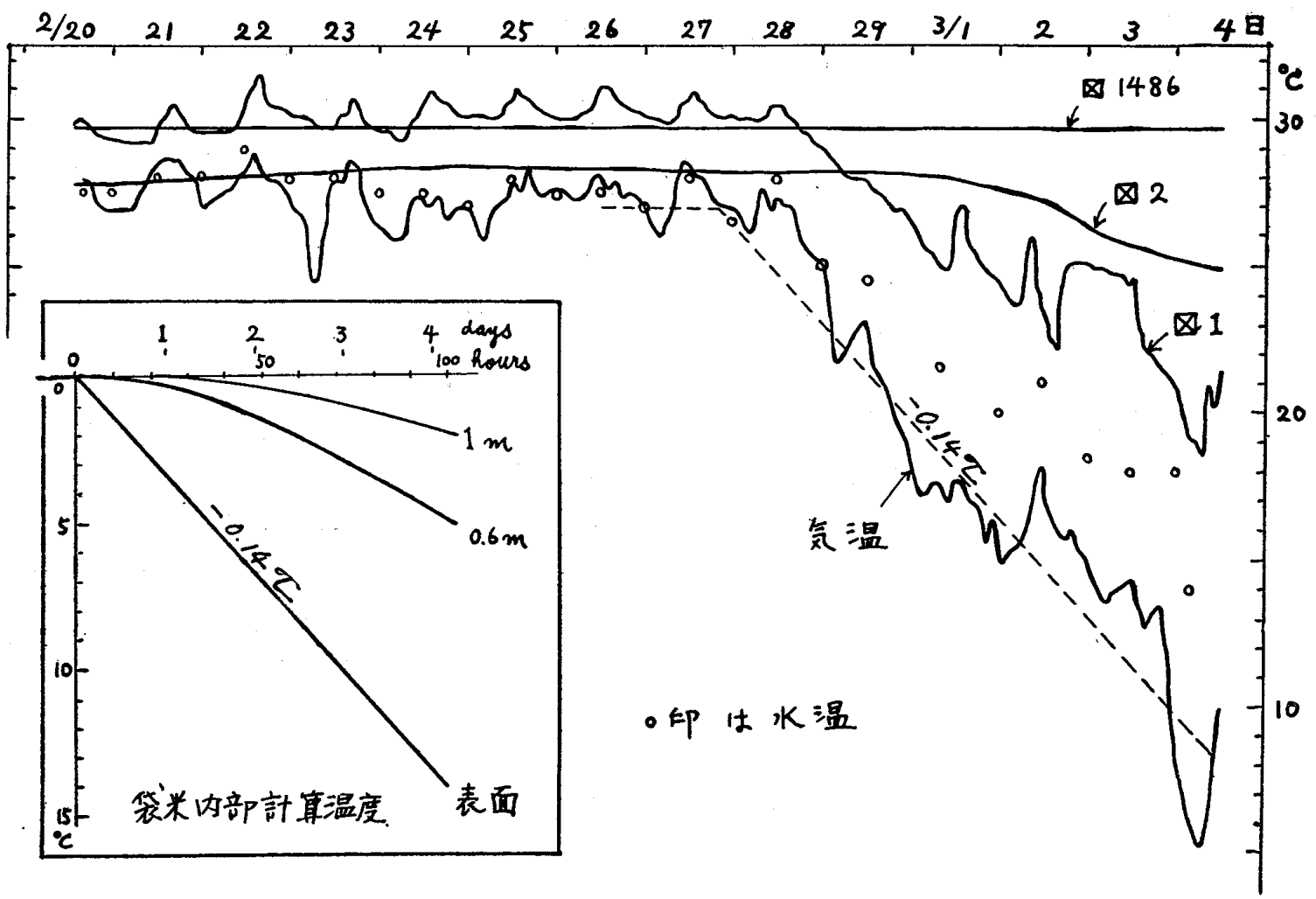


附国6 米哈水率々南保湿度

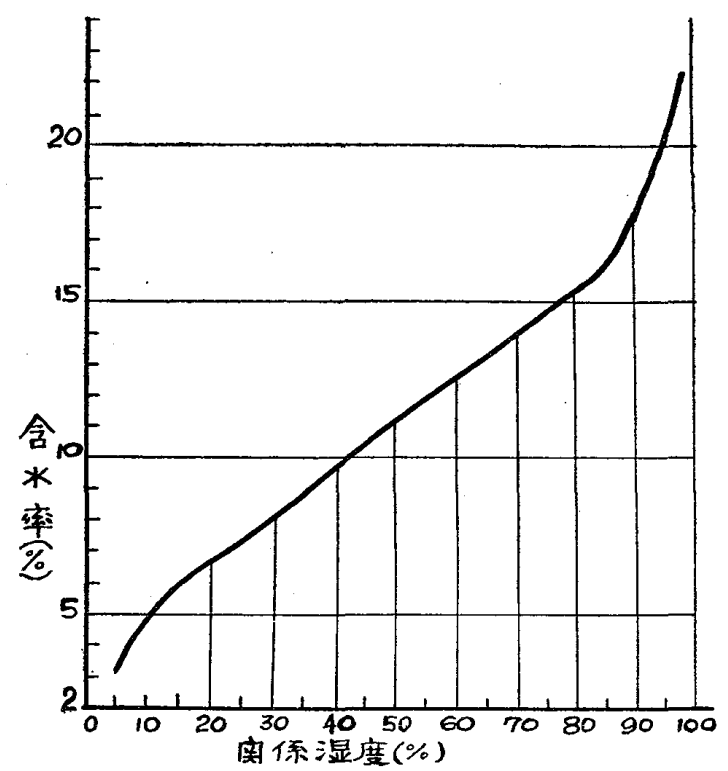

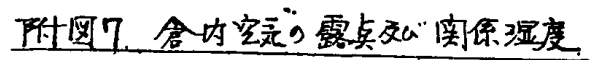
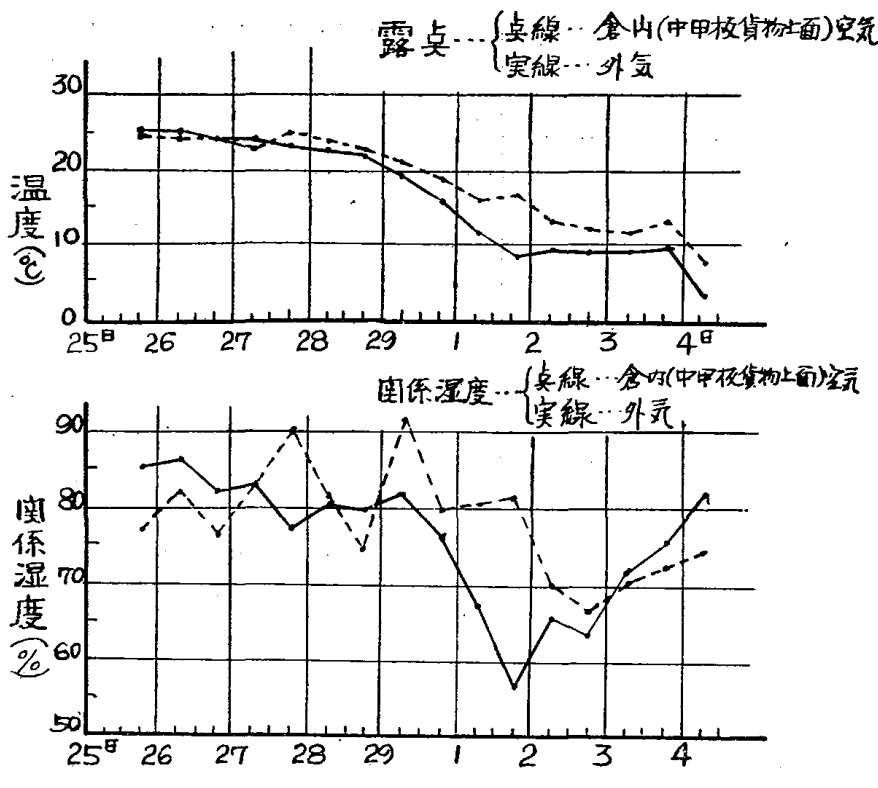

表 1 ビルマ米平均含水率

\begin{tabular}{|ccc|c|c|}
\hline 積 & 荷 & 時 & $12.8 \%$ & Kett 電気抵抗式豰類水分計による測定值 \\
\hline 揚 & 荷 & 時 & 12.4 & \\
\hline & $\prime$ & 13.6 & 大阪食糧事務所の乾燥式水分計による測定值 \\
\hline
\end{tabular}

航海中の含水率変化 (中甲板上面)

\begin{tabular}{|c|c|c|}
\hline 2 月 28 日 & $13.4 \%$ & Kett 電気抵抗式款類水分計による測定值 \\
\hline 29 & 13.5 & \\
\hline 3 月 1 日 & 14.0 & \\
\hline 2 & 13.5 & \\
\hline 3 & 13.3 & \\
\hline
\end{tabular}


表 2 中甲板貨物上面温度変化

\begin{tabular}{|c|c|c|}
\hline 月 & 高 $\left({ }^{\circ} \mathrm{C}\right)$ & 低 $\left({ }^{\circ} \mathrm{C}\right)$ \\
\hline 2 月 20 日 & $\begin{array}{c}38.0 \\
.\end{array}$ & 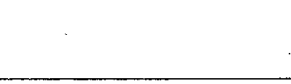 \\
\hline 21 & 46.5 & 27.0 \\
\hline 22 & 46.5 & 29.0 \\
\hline 23 & 53.0 & 26.0 \\
\hline 24 & 41.5 & 27.0 \\
\hline 25 & 45.0 & 28.0 \\
\hline 26 & 43.0 & 28.0 \\
\hline 27 & 46.5 & 26.0 \\
\hline
\end{tabular}

参考文献

1) 渡辺要 建築計画原論 P209

2) 渡辺要 建築計画原論 P209

3) 渡辺要 建築計画原論 P196

4) 渡辺要 建築計画原論 P180

5）高橋安人訳 シャック応用伝熱 P167

6）高橋安人訳 シャック応用伝熱 P88.93.

7) 高橋安人訳 シャツク応用伝熱 P167.

8) Carslaw and Jaeger, Conduction of Heat in Solids 1947, P45.

9) Carslaw and Jaeger, Conduction of Heat in Solids 1947, P56.

10) Carslaw and Jaeger, Conduction of Heat in Solids 1947, P57.

11）内藤広，食糧研究所研究報告第10号“米穀の含有水分量と関係湿度との関係について” P41. 